\title{
Use of geometric morphometrics to identify ecophenotypic variation of juvenile Persian sturgeon Acipenser persicus
}

\author{
Shima Bakhshalizadeh ${ }^{1}$, Ali Bani ${ }^{1,2}$ \\ ${ }^{1}$ Department of Biology, Faculty of Science, University of Guilan, Namjo Street, Rasht, Postal Code 41335-1914, Iran. \\ (SB) (Corresponding author) E-mail: shima@phd.guilan.ac.ir. ORCID-iD: http://orcid.org/0000-0002-2683-579X \\ (AB) E-mail: bani@guilan.ac.ir. ORCID-iD: http://orcid.org/0000-0002-6087-926X \\ ${ }^{2}$ Department of Marine Science, Caspian Sea Basin Research Centre, University of Guilan, Rasht, Iran.
}

\begin{abstract}
Summary: Study of phenotypic variation is essential for identifying discrete phenotypic stocks. We sampled immature Persian sturgeon from the eastern and western portion of the southern Caspian Sea to test for morphological differences that could predict the ecophenotypic variation of Persian sturgeon. Geometric morphometric methods were used to quantify body shape. Configuration of landmark coordinates of fish body were scaled, translated and rotated using generalized Procrustes analysis, followed by univariate analysis of variance of resulting shape coordinates to evaluate potential morphological differences between regions. A principal component analysis was carried out to reduce the number of dimensions without the loss of information. The discriminate function analysis was performed to determine the efficacy of body landmarks for discrimination by geographic variants. Within-group linkage was inferred for dendrogram clusters using Pearson correlation distance on the basis of the average linkage method as a complement for discriminate analysis. Principle component analysis revealed that the largest differences were in body size. Most notable were differences in distance between head landmarks and the dorsal fin between eastern and western regions. Fish from the western region exhibited a longer distance from head landmarks to the dorsal fin than fish from the eastern region. Furthermore, the ventral portion of fish from the western region was longer than that of the eastern individuals. These findings show that juvenile Persian sturgeon already possess morphological traits that can be used to discriminate fish from different regions. Furthermore, these differences are discernible in spite of the volume of artificially-inseminated sturgeon larva that have been released during the past 40 years.
\end{abstract}

Keywords: geometric morphometric selection, phenotypic plasticity, discrimination, habitat.

Uso de morfometría geométrica para la identificación de variaciones ecofenotípicas en juveniles de esturión persa Acipenser persicus

Resumen: El estudio de la variación fenotípica es esencial para la identificación de estirpes fenotípicas concretas. Con el fin de identificar diferencias morfológicas que permitan predecir variaciones eco-fenotípicas en el esturión persa, individuos inmaduros de esta especie se muestrearon en diferentes regiones del este y el oeste del sur del mar Caspio. Se utilizaron métodos morfométricos geométricos para cuantificar la forma del cuerpo. La configuración de coordenadas referenciadas del cuerpo del pez fueron escaladas, trasladadas y rotadas utilizando el análisis generalizado Procrustes, seguido del análisis Univariante de la Varianza de las coordenadas de forma resultantes, con el fin de evaluar posibles diferencias morfológicas entre diferentes zonas. Se utilizó un análisis de componentes principales para reducir el número de dimensiones sin perder información. Los scores de los componentes del cuerpo se sometieron a análisis discriminante, con el objeto de determinar la eficacia de las coordenadas referenciadas en la discriminación de las variantes geográficas. Las relaciones entre grupos para clusters de dendrograma se infirieron usando la correlación de distancias de Pearson, tomando como base el método de relación media como complemento del análisis discriminante. El análisis de componentes principales reveló que las mayores distancias fueron en la talla. Destacaron las diferencias encontradas en la distancia entre las referencias de cabeza y aleta dorsal entre las regiones del Este y Oeste. La distancia relativa entre las referencias de cabeza y aleta dorsal fue mayor en los peces de la región Oeste que en los de la región Este. Además, la porción ventral de los peces de la región Oeste fue mayor que la de los individuos del Este. Estos resultados indican que los juveniles de esturión persa ya muestran características morfológicas que pueden utilizarse para la discriminación de individuos de diferentes regiones. Además, estas diferencias son discernibles a pesar de la cantidad de larvas de esturión que, obtenidas por inseminación artificial, han sido liberadas al medio natural durante los últimos 40 años.

Palabras clave: selección morfométrica geométrica; plasticidad fenotípica; discriminación; habitat.

Citation/Como citar este artículo: Bakhshalizadeh S., Bani A. 2017. Use of geometric morphometrics to identify ecophenotypic variation of juvenile Persian sturgeon Acipenser persicus. Sci. Mar. 81(2): 187-193. doi: http://dx.doi.org/10.3989/scimar.04487.01A

Editor: E. Mañanos.

Received: June 6, 2016. Accepted: February 27, 2017. Published: April 25, 2017.

Copyright: (C) 2017 CSIC. This is an open-access article distributed under the terms of the Creative Commons Attribution (CC-by) Spain 3.0 License. 


\section{INTRODUCTION}

Phenotypic plasticity is the potential of the observable characteristics of a genotype to change in response to different environmental stimuli (Cadrin 2000). Investigating phenotypic responses in fish began in the mid-20th century, and has played an important role in our understanding of biological diversity in fishes by relating their forms to their ecological roles (Motta et al. 1995). Factors such as stock density, aggressiveness, stress, type and quality of food, swimming performance and fish mobility concordant with depth, salinity, temperature and sea floor substrate influence the presence of polymorphisms in fishes (Favaloro and Mazzola 2003, Hanson et al. 2007, Cadrin 2014). However, morphometric analyses of sturgeon fish to assess the degree of phenotypic plasticity in this species have rarely been conducted (Hilton and Schaefer 2002). Instead, morphological differences between wild and hatchery-reared sturgeon (Ruban and Sokolov 1986, Ruban 1989) have been described for stock identification (Guenette et al. 1992, Keenlyne et al. 1994) and subspecies identification (Vasil'eva 2009). On the other hand, for different species the level of phenotypic plasticity has been well documented (Cramon-Taubadel et al. 2005, Wintzer and Motta 2005, Wessel et al. 2006). For example, smolts reared for 25 months in different marine net-pen areas had significant size differences in the caudal peduncle, trunk, and head regions that were associated with water characteristics (Sheehan et al. 2005). Juvenile Trachurus japonicus has the streamlined body for feeding on larval Engraulis japonicus in coastal waters, whereas the compressed morphology of these juveniles is adaptive to associate with jellyfishes in offshore waters (Kishida et al. 2011). Additionally, local populations of arctic char (Salvelinus alpinus) with different feeding habits have different mouth shapes (Cadrin 2014).

It has been postulated that the pattern of morphometric variation in fish may indicate differences in life history, such as growth and maturation rates, because body form is a product of ontogeny (Cadrin 2014). Moreover, phenotypic stock definition is not as conservative as the definition of genetic stock, because the definition for phenotypic stock permits more mixing among stocks. Nevertheless, geographic differences can persist despite incomplete (partial) isolation of fish stocks (Cadrin 2014). Furthermore, life-history traits can influence population attributes. Therefore, distinct fish populations should be modelled and managed separately in regard to stock assessment, regardless of genetic homogeneity.

The Persian sturgeon, Acipenser persicus (Borodin, 1897), is distributed mostly in the Caspian Sea, while smaller numbers exist in the Black Sea, and it is listed as a threatened species in the International Union for Conservation of Nature (IUCN). Fish stock abundance in the Caspian Sea can be attributed mostly to artificial insemination and release by Iranian fish propagation centres. The Persian sturgeon is also the most important commercial sturgeon in the Iranian waters of the Caspian Sea, as more than $60 \%$ of sturgeon catches contain the Persian sturgeon (Moghim et al. 2006). Juvenile Persian sturgeon are more abundant in the Iranian coastal waters of the Caspian Sea (Tavakoli et al. 2009) and feed mainly on crustaceans (mostly gammarids) and Nereis, Nereis diversicolor. In the southern Caspian Sea, the maximum density of these prey items is found at depths $<50 \mathrm{~m}$ (Mirzajani et al. 2005), while they are less dense in deeper waters (Dumont 1998).

Physical differences in water temperature, water velocity and salinity between western and eastern coastal waters of the Caspian Sea, especially in the nursery areas of the Sefidrood and Gorganrood rivers (Mazlomi et al. 2009), are the presumed drivers of ecological differences of the Caspian Sea fishes. In this study, we investigated the influence of geographical differences on the morphology of juvenile Persian sturgeon, $A$. persicus, which are widely distributed in the southern Caspian Sea, because of poorly documented morphologies of acipenserid species that are unique to particular stocks of the Ponto-Caspian region (Vecsei and Peterson 2005). Here, we provide the first assessment of how the morphology of juvenile Persian sturgeon varies with geography. These patterns of phenotypic variation are essential for identifying discrete phenotypic stocks as we attempt to fill in the gaps regarding morphological characters of juvenile Persian sturgeon in the Iranian coastal waters of the Caspian Sea.

\section{MATERIALS AND METHODS}

Samples were obtained from commercial fishery catches in the western and eastern areas (Fig. 1) of the coastal Iranian waters of the Caspian Sea $\left(38^{\circ} 26^{\prime} \mathrm{N}\right.$, $49^{\circ} 54^{\prime} \mathrm{E}$ and $36^{\circ} 49^{\prime} \mathrm{N}, 52^{\circ} 48^{\prime} \mathrm{E}$, respectively) in order to examine geographic variation of morphological characters (i.e. the landmark value). We examined 26 juveniles from the western section (total length $\left(\mathrm{L}_{\mathrm{T}}\right)$, $33.67 \pm 13.35 \mathrm{~cm}$; total weight $\left.\left(\mathrm{W}_{\mathrm{T}}\right), 121.04 \pm 15.17 \mathrm{~g}\right)$ and 14 juveniles from the eastern section (total length $\left(\mathrm{L}_{\mathrm{T}}\right), 34.43 \pm 7.74 \mathrm{~cm}$; total weight $\left(\mathrm{W}_{\mathrm{T}}\right), 111.21 \pm 8.14$ g) were collected between October 2012 and June 2015

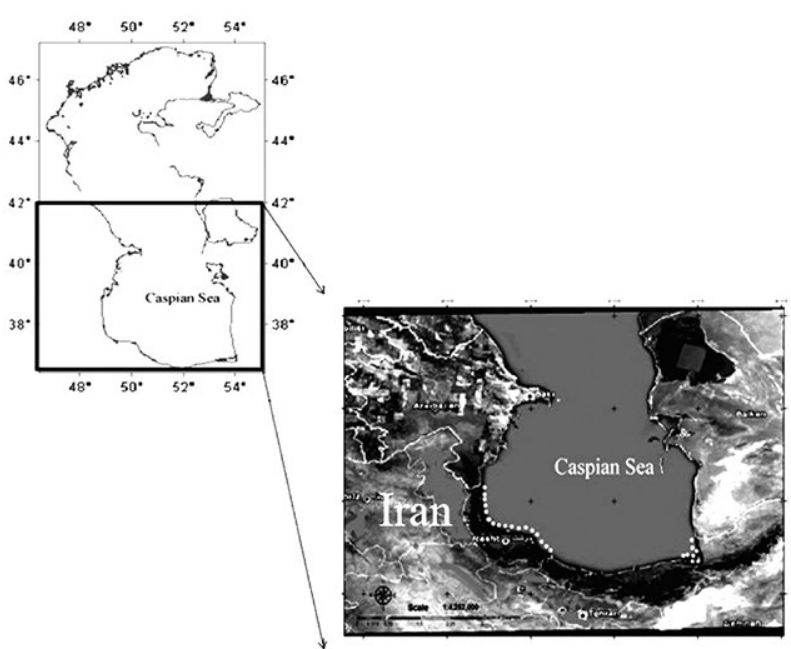

Fig. 1. - Location of sampling areas (white closed circles) of juvenile Persian sturgeon in Iranian coastal waters of the Caspian Sea between October 2012 and June 2015. 


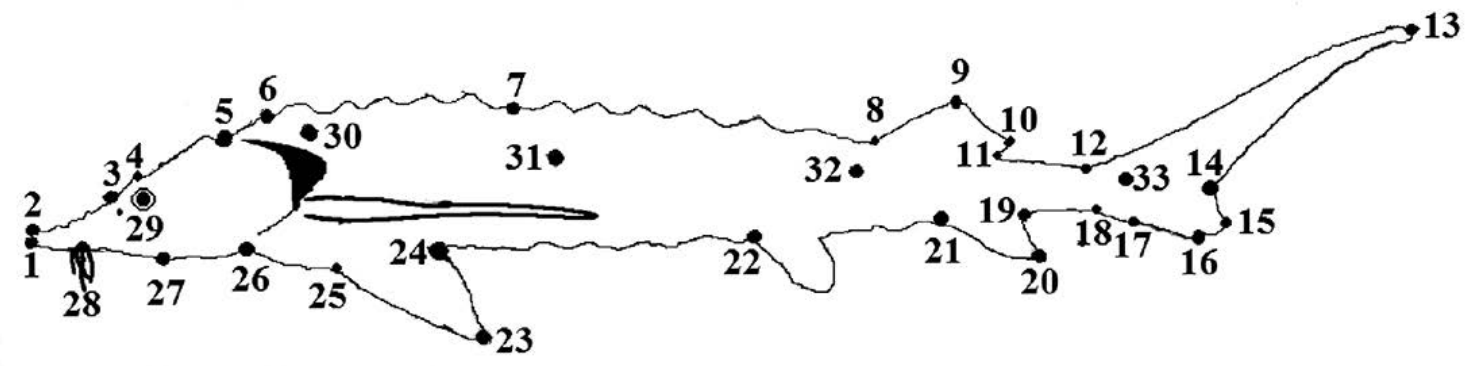

Fig. 2. - Configuration of 33 landmarks for geometric morphometrics of juvenile Persian sturgeon. Landmarks are defined as follows: (1) and (2) snout tip, (3) top of nares, (4) top of eye, (5) dorsal margin of head directly above, (6) position of the first dorsal scut, (7) position of the middle dorsal scut, (8) anterior insertion of the dorsal fin, (9) maximum height of dorsal fin, (10) minimum height of dorsal fin, (11) posterior insertion of the dorsal fin, (12) and (18) end of caudal peduncle, (13) point of the superior caudal fin, (14) point of fork caudal fin, (15) and (16) anterior and posterior of inferior section of caudal fin lobe, (17) point of the middle semilunar inferior caudal fin lobe, (19) and (21) posterior and anterior insertion of the anal fin, (20) point of the superior anal fin, (22) insertion on the profile of the pelvic fin, (23) point of the superior pectoral fin, (24) and (25) posterior and anterior insertion of the pectoral fin, (26) caudoventral point of the suboperculum, (27) point of the mouth, (28) point of the barbel, (29) center of the eye; (30), (31), (32) and (33) were set for fitting the cubic curve to correct for unnatural dorso-ventral bend.

and were kept in the similar conditions. At this size, sturgeons are immature and exhibit no growth difference between sexes.

Geometric morphometric methods were used to quantify body shape (Zelditch et al. 2012). Photographs of the right side of each raw specimen were taken with a W270 digital camera (Sony, Japan) and then analysed using the tps software package (http://life.bio.sunysb.edu/morph). The camera was set approximately $1.5 \mathrm{~m}$ from the specimen to minimize potential wide-angle artefacts. The thin plate spline (tps) functions implemented by the software describe

Table 1. - Significant results of ANOVA for morphometric character of the body shape of juvenile Persian sturgeon (Acipenser persicus) as described by landmarks collected from the western and eastern Iranian coastal water of the Caspian Sea between October 2012 and June 2015. $\mathrm{P}$ is regarded as being significant if $<0.05$ (ANOVA).

\begin{tabular}{|c|c|c|c|c|c|c|c|c|}
\hline Character & $\mathrm{F}$ value & $\mathrm{P}$ value & Character & F value & $\mathrm{P}$ value & Character & F value & $\mathrm{P}$ value \\
\hline $1-8$ & 4.89 & 0.03 & $8-9$ & 5.58 & 0.02 & $16-32$ & 11.01 & 0.00 \\
\hline $1-11$ & 5.02 & 0.03 & $8-13$ & 6.32 & 0.02 & $17-18$ & 4.69 & 0.04 \\
\hline $1-21$ & 4.93 & 0.03 & $8-16$ & 12.34 & 0.00 & $17-20$ & 6.24 & 0.02 \\
\hline $1-23$ & 5.00 & 0.03 & $8-17$ & 5.24 & 0.03 & $17-23$ & 13.85 & 0.00 \\
\hline $1-32$ & 4.58 & 0.03 & $8-20$ & 7.29 & 0.01 & $17-32$ & 6.39 & 0.02 \\
\hline $2-8$ & 6.60 & 0.01 & $8-23$ & 19.36 & 0.00 & $18-20$ & 16.00 & 0.00 \\
\hline $2-11$ & 7.16 & 0.01 & $8-27$ & 5.74 & 0.02 & $18-23$ & 17.70 & 0.00 \\
\hline $2-21$ & 6.80 & 0.01 & $8-28$ & 7.04 & 0.01 & $18-28$ & 4.86 & 0.03 \\
\hline $2-22$ & 4.75 & 0.03 & $8-29$ & 5.27 & 0.03 & $19-23$ & 15.70 & 0.00 \\
\hline $2-32$ & 5.36 & 0.03 & $9-20$ & 8.05 & 0.01 & $19-32$ & 5.08 & 0.03 \\
\hline $3-8$ & 6.66 & 0.01 & $9-23$ & 17.37 & 0.00 & $20-21$ & 5.93 & 0.02 \\
\hline $3-11$ & 7.99 & 0.01 & $9-32$ & 7.09 & 0.01 & $20-22$ & 4.92 & 0.03 \\
\hline $3-18$ & 4.17 & 0.04 & $10-11$ & 5.13 & 0.03 & $20-23$ & 6.92 & 0.01 \\
\hline $3-21$ & 8.55 & 0.01 & $10-13$ & 4.71 & 0.04 & $20-31$ & 8.44 & 0.01 \\
\hline $3-22$ & 5.39 & 0.03 & $10-16$ & 6.50 & 0.02 & $20-32$ & 8.61 & 0.01 \\
\hline $3-23$ & 4.41 & 0.04 & $10-20$ & 5.13 & 0.03 & $20-33$ & 17.57 & 0.00 \\
\hline $3-28$ & 6.23 & 0.02 & $10-23$ & 17.03 & 0.00 & $21-23$ & 18.85 & 0.00 \\
\hline $3-32$ & 5.53 & 0.02 & $11-13$ & 6.69 & 0.01 & $21-27$ & 8.14 & 0.01 \\
\hline $4-8$ & 6.09 & 0.02 & $11-16$ & 11.66 & 0.00 & $21-28$ & 9.06 & 0.01 \\
\hline $4-11$ & 6.44 & 0.02 & $11-17$ & 5.43 & 0.03 & $22-23$ & 12.78 & 0.00 \\
\hline $4-21$ & 7.20 & 0.01 & $11-23$ & 21.59 & 0.00 & $22-28$ & 5.14 & 0.03 \\
\hline $4-23$ & 5.70 & 0.02 & $11-27$ & 6.64 & 0.01 & $22-29$ & 4.75 & 0.04 \\
\hline $4-32$ & 5.24 & 0.03 & $11-28$ & 6.77 & 0.01 & $23-24$ & 7.92 & 0.01 \\
\hline $5-6$ & 16.15 & 0.00 & $12-20$ & 11.94 & 0.00 & $23-25$ & 10.06 & 0.00 \\
\hline $5-8$ & 9.98 & 0.00 & $12-23$ & 12.93 & 0.00 & $23-26$ & 10.57 & 0.00 \\
\hline $5-10$ & 5.38 & 0.03 & $12-32$ & 6.03 & 0.02 & $23-27$ & 6.33 & 0.02 \\
\hline $5-11$ & 10.03 & 0.00 & $13-23$ & 7.60 & 0.01 & $23-28$ & 4.40 & 0.04 \\
\hline $5-14$ & 5.18 & 0.03 & $13-31$ & 7.03 & 0.01 & $23-29$ & 8.26 & 0.01 \\
\hline $5-18$ & 8.17 & 0.01 & $13-32$ & 8.34 & 0.01 & $23-30$ & 5.23 & 0.03 \\
\hline $5-19$ & 5.55 & 0.02 & $14-16$ & 5.32 & 0.03 & $23-32$ & 19.97 & 0.00 \\
\hline $5-21$ & 12.87 & 0.00 & $14-20$ & 10.67 & 0.00 & $23-33$ & 18.24 & 0.00 \\
\hline $5-22$ & 5.35 & 0.03 & $14-23$ & 16.68 & 0.00 & $25-30$ & 12.23 & 0.00 \\
\hline $5-24$ & 5.63 & 0.02 & $14-32$ & 4.86 & 0.03 & $26-27$ & 4.83 & 0.03 \\
\hline $5-27$ & 6.63 & 0.01 & $15-16$ & 5.78 & 0.02 & $26-28$ & 5.16 & 0.03 \\
\hline $5-28$ & 4.33 & 0.04 & $15-20$ & 9.99 & 0.00 & $26-30$ & 14.93 & 0.00 \\
\hline $5-31$ & 4.80 & 0.04 & $15-23$ & 18.70 & 0.00 & $27-32$ & 5.23 & 0.03 \\
\hline $5-32$ & 6.98 & 0.01 & $15-32$ & 5.04 & 0.03 & $28-32$ & 5.62 & 0.02 \\
\hline $5-33$ & 5.42 & 0.03 & $16-18$ & 9.72 & 0.00 & $29-32$ & 8.17 & 0.01 \\
\hline 6-30 & $\begin{array}{l}5.42 \\
5.35\end{array}$ & 0.03 & $16-19$ & 7.08 & 0.01 & $30-31$ & 5.53 & 0.02 \\
\hline $7-13$ & 5.06 & 0.03 & $16-21$ & 7.53 & 0.01 & $30-32$ & 8.99 & 0.01 \\
\hline $7-16$ & 4.98 & 0.03 & $16-23$ & 9.17 & 0.00 & $32-33$ & 4.38 & 0.04 \\
\hline $7-20$ & 4.35 & 0.04 & $16-31$ & 7.93 & 0.01 & & & \\
\hline
\end{tabular}



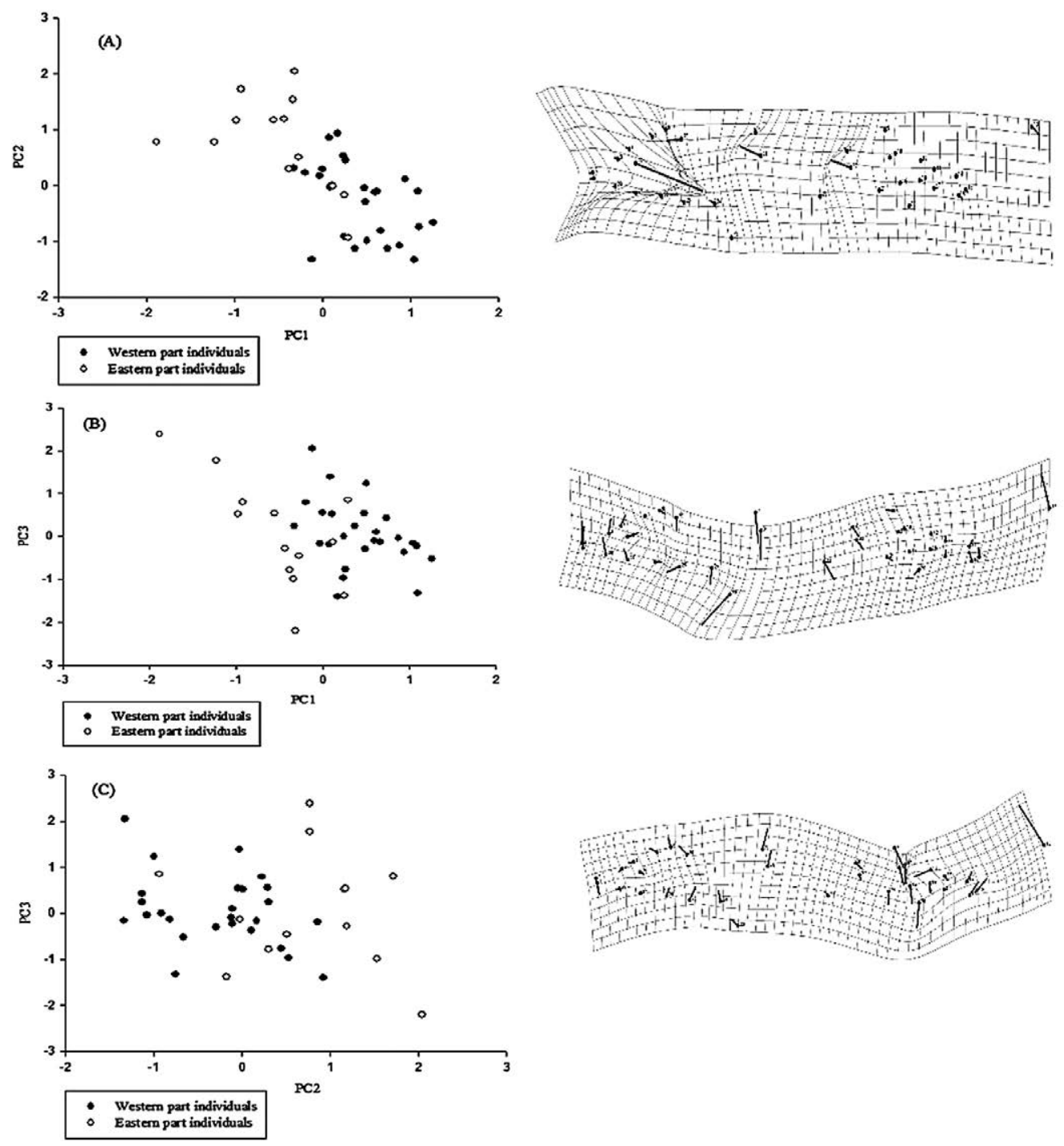

Fig. 3. - Landmark-based method scores from principal component analysis of juvenile Persian sturgeon for body shape in two regions. The scatter plot shows individual fish scores for PC1 vs. PC2 (A), PC1 vs. PC3 (B) and PC2 vs. PC3 (C), which together explain the total variance of $75.79 \%$. Deformation grids (splines) are reported on the right side of each scatter plot. The splines represent fish shape variability along each relative PC axis.

statistical variation in deformation of a thin sheet. After first concatenating all photographs into a single file, we used 33 morphological landmarks (Fig. 2) that were placed in the tps Dig 2 program (Rohlf 2006). Because sturgeons have relatively soft bodies, specimens generally assume unnatural body positions. We placed four references along the midline of each specimen as internal landmarks (Bookstein 1997). These could be used to fit a cubic curve to correct for the unnatural body positions of specimens. The confounding effects of rotation, translation and scaling were eliminated by employing a generalized least-squares procedure. Procrustes superimposition using PAST software, uniform components and centroid size for each specimen were achieved for subsequent analysis according to Zelditch et al. (2012).

Data were first checked for normality and homogeneity of variances (Levene test). Univariate analysis of variance (ANOVA) was tested in length and weight of juveniles to compare size of fish between regions. Moreover, ANOVA was applied for each morphometric character as described by landmarks, to evaluate size and potential morphological differences between regions (Zar 1996), and only the significant results of ANOVA for morphometric measurements as distance between points of the body shape were kept and submitted for the subsequent process.

Principal components analyses (PCAs) were carried out to reduce the number of Procrustes shape coordinates without the loss of information (Quinn and Keough 2002). The scree plot (eigenvalues against principal component number) and cumulative variance values were generated to identify the principal components that explained the majority of variation in body shape. The discriminate function analysis was performed to determine the efficacy of body landmarks for discrimination by geographic variants and to calculate the percentage of fish that were correctly clas- 
sified to their population of origin. A cross-validation was done to assay the expected actual error rates of the classification functions. Within-group linkage was inferred for dendrogram clusters using Pearson correlation distance on the basis of average linkage method as a complement for discriminate analysis to classify fish efficacy of body landmarks.

All statistical analyses were performed using SPSS (SPSS Inc., Chicago, IL) and PAST (Paleontological Statistics, version1.81) software. Significance level was set at $\alpha=0.05$ for statistical tests.

\section{RESULTS}

No significant differences were detected in mean body length $\left(\mathrm{L}_{\mathrm{T}}\right)$ (t test $=-0.40$, d.f. $=38, \mathrm{P}=0.69$ ) or mean weight $\left(\mathrm{W}_{\mathrm{T}}\right)(\mathrm{t}$ test $=0.46$, d.f. $=38, \mathrm{P}=0.65)$ of juvenile sturgeon from the western and eastern coastal waters of the Iranian Caspian Sea. However, most of the morphometric characters described by landmarks of juvenile sturgeon from the western and eastern coastal waters were significantly different $(\mathrm{P}<0.05)$ (Table 1$)$.

Principle components analysis revealed that $75.8 \%$ of the total variation in body morphology was due to the first six components that explained $38.60 \%$, $15.32 \%, 7.22 \%, 5.75 \%, 4.65 \%$ and $4.25 \%$ of the total variation, respectively (Fig. 3) The first principal component (PC1) mainly described body shape. Distance between head landmarks to dorsal fin area differed between fish from the western and eastern coastal waters. There was a significant difference between the landmark regions that had the largest eigenvalue $(>0.8)$ loaded in PC1(29-32, 5-32, 23-32, 4-32, 3-32, 28-32, 27-32, 8-29, 6-32, 2-32, 1-32, 30-32, 22-29, 5-31, 8-28 and 5-8) $(\mathrm{P}<0.05)$ (Table 1$)$. Fish from the western region were characterized by a longer distance from head landmarks to the dorsal fin area than fish from the eastern region, so the anterior part of the body of western fish is more elongated than that of fish from the eastern region. The head section of the body had shown the most differences but the end of the body was less different. Therefore, the best contrast between individuals is achieved by comparing head length traits with end body traits. This means that the head was smaller, eyes were lower than the main body axis, the base of the pectoral fin was located closer to the head, the height of the caudal fin was lower than the main body axis, median scutes were above the main body axis and length of the caudal peduncle was increased (Fig. 3).

Differences in morphological characteristics of the body of fish from the two regions were primarily described with one function. This function separates fish from the two regions by explaining $100 \%$ of the variation in body shape. The cross-validated classification in the discriminate analysis indicates that $84.6 \%$ of all western region juveniles and $78.6 \%$ all eastern region juveniles were assigned to the correct geographic provenance. The difference in morphology of body shape was significant (Wilk's lambda $=0.01, \chi^{2}=42.99$, d.f. $=23, \mathrm{P}<0.05)$. The discriminant function is predominantly correlated with the position of the dorsal fin attitude to the head (2-8 landmarks). Juvenile Persian

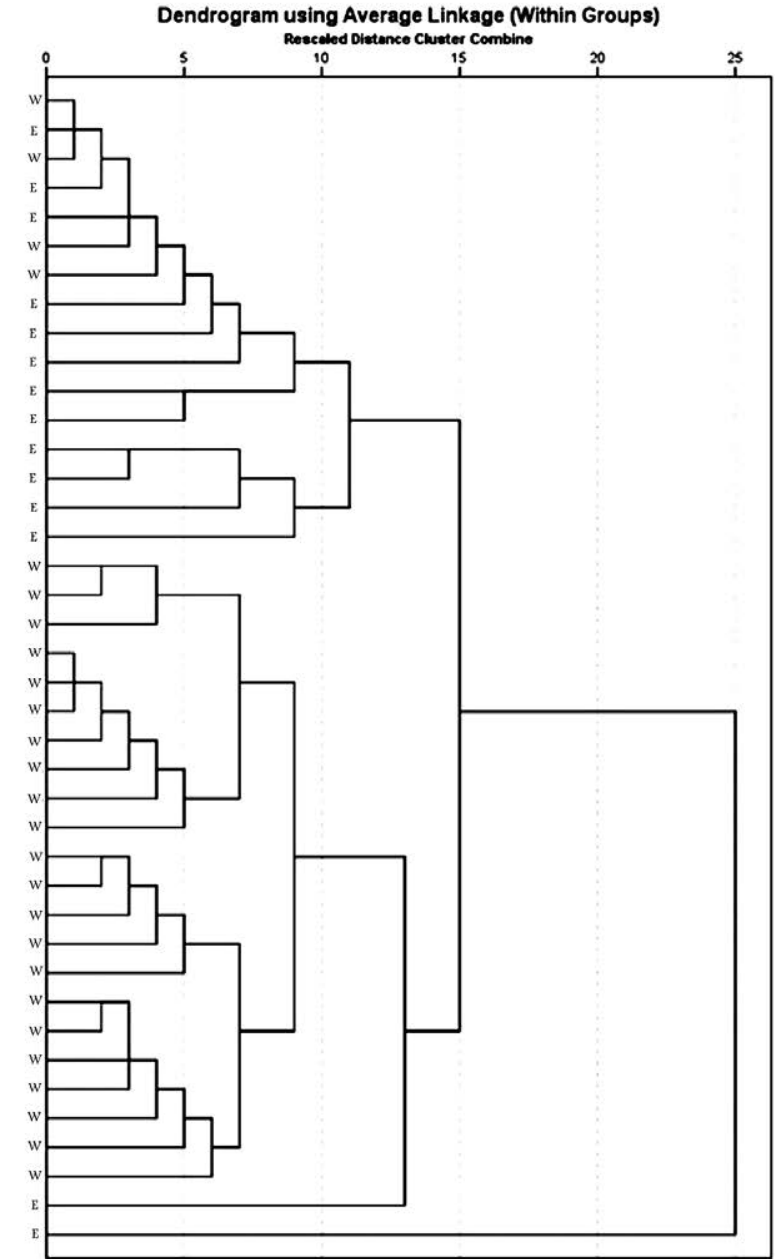

Fig. 4. - Landmark-based method dendrogram derived from cluster analysis showing the relationships between body shape of juvenile Persian sturgeon in two regions. E represents eastern part individual body shape and $\mathrm{W}$ represents western part individual body shape.

sturgeon from the western region are more elongated than fish from the eastern region $(\mathrm{P}<0.05)$ (Table 1$)$.

The dendrogram (Fig. 4) grouped the two regions into two major subgroups. All samples, except one individual from the eastern region and four individuals from the western region, were classified into two main subgroups. The analysis of landmark data from body shape of juvenile Persian sturgeon shows two main phenotypic groups that reflect the geographical distribution of juvenile Persian sturgeon in the Iranian coastal waters of the Caspian Sea.

\section{DISCUSSION}

Body shape of Persian sturgeon from the eastern and western coastal Iranian waters of the Caspian Sea are sufficiently distinct to allow the discrimination of the two ecophenotypes based on discriminant function and morphometric indices. Morphological distinction may be explained by differences in local adaptation (Kishida et al. 2011). Adaptation involves maintenance of characters that improve survival and reproduction of individuals. With the potential to identify discrete stocks phenotypically, analysis of 
morphometric landmarks is a valuable tool that complements other stock identification methods such as molecular approaches. Monet et al. (2006), EspinosaLemus et al. (2009) and Tancioni et al. (2013) demonstrated that morphometric and genetic data were complementary for stock identification. The identification of discrete 'phenotypic' stocks is essential for population modelling. This is important because it is generally assumed that ontogenetic rates are homogeneous within stocks (Cadrin 2014).

Several studies have stated that body shape should be attributed to genetic differences and environmental effects (Albertson et al. 2003, Toscano et al. 2010, Cadrin 2014). Although gene flow between the western and eastern stocks of Persian sturgeon in the Iranian waters of the Caspian Sea (Khoshkholgh et al. 2011) occurs, our findings showed that juvenile sturgeon from the different regions were well segregated by body shape analysis. Morphological variation among different short-nosed sturgeon, Acipenser brevirostrum, were explained by environmental traits and also by differential grow rates during larval development (Walsh et al. 2001, Russo et al. 2009). For example, differences in head proportions as a result of different growth rates were seen in different populations of lake sturgeon, Acipenser fulvescens (Guenette et al. 1992). Moreover, differential water temperature and velocity influenced morphology among Siberian sturgeon populations, Acipenser baeri (Ruban and Sokolov 1986). The streamlined body of juvenile Persian sturgeon from the western region of the Iranian coast is adapted for high flow rates, which decreases body drag (reduction in head and body depth) (Taft 2011) in comparison with juveniles from the eastern region. Fin characteristics were different in the two regions. These types of adaptations were seen in juveniles reared in lakes, which had more posteriorly-placed pectoral fins (Langerhans and Reznick 2010, Cadrin 2014), as we see in juveniles from the eastern coastal waters.

Furthermore, trophic niche could be affected on morphological diversity in body shape of larval stage of fish, particularly in the head region (Russo et al. 2007, 2008, 2012).

Differences in water temperature and seasonal variation in ecological conditions may also cause varying selection pressure on growth and morphology (Pakkasmaa and Piironen 2001). Slower growth rate could be responsible for the these differences in head proportions (Guenette et al. 1992). Larger head and body proportions are observed in individuals that grow slowly. Juvenile Persian sturgeon from the eastern region, which is marked by higher water temperature, have bigger fins than juveniles from the western region. At optimal temperatures, growth and development proceed more rapidly, while at sub-optimal high or low temperatures, growth and development are slow and led to larger fins, as observed in the early life stage of the short-nosed sturgeon, Acipenser brevirostrum (Walsh et al. 2001). The average surface temperature is generally higher in the eastern region than in the western region (Ginzburg et al. 2005). Abdolhay et al. (2010) suggested that different populations of kutum, Rutilus frisii kutum, in the southern Caspian Sea could be differentiated by physical characteristics of each habitat, such as water temperature. If the observed variation in phenotype results from plasticity, then population-level morphology may be a response to altered hydrology. Regardless of a plastic or adaptive response, the strength of selection and underlying genetic diversity will influence how quickly populations will need to change in order to persist (Michel et al. 2014).

The phenotypic plasticity in body shape between eastern and western portions of the Iranian coastal waters of the Caspian Sea suggests that Acipenser persicus has an adaptive response. Therefore, body shape could be useful for distinguishing between stocks where it is impossible to follow fish larvae from hatching or even release, and could thus be a useful tool in conservation biology, population restoration and commercial fishery management.

\section{ACKNOWLEDGEMENTS}

We wish to thank Dr Ronald J. Sarno for excellent comments and for editing the English language text of this manuscript. Sampling authorization was given by the Iranian Fisheries Organization. We would also like to thank M.H. Mazarei, A. Rostamzadeh, A. Fomani, A. Kor, M.R. Omidi, M. Hajipour, F. Fadavi, S. Bakhshalizadeh and K. Bakhshalizadeh for their assistance in the collection of the fish. Many thanks to S. Khataminejad and two anonymous reviewers for their helpful comments on the manuscript. We also thank Dr A. Seidavi and Dr S. Abdolmalaki for their spiritual support. This research was supported by the University of Guilan, and the Mohamed bin Zayed Species Conservation Fund.

\section{REFERENCES}

Abdolhay H.A., Khalijah D.S., Pourkazemi M., et al. 2010. Morphometrics studies of Mahisefid (Rutilus frisii kutum, Kamensky, 1901) from selected rivers in the southern Caspian Sea. Iranian J. Fish. Sci. 9: 1-18.

Albertson R.C., Streelman J.T., Kocher T.D. 2003. Genetic basis of adaptive shape differences in the cichlid head. J. Hered. 94: 291-301.

https://doi.org/10.1093/jhered/esg071

Bookstein F.L. 1997. Morphometric tools for landmark data: geometry and biology. Cambridge University Press.

Cadrin S.X. 2000. Advances in morphometric identification of fishery stocks. Rev. Fish Biol. Fish. 10: 91-112. https://doi.org/10.1023/A:1008939104413

Cadrin S.X. 2014. Morphometric landmarks, In: Cadrin S.X., Kerr L.A., Mariani S. (eds), Stock identification methods: Applications in fishery science. Academic Press. Elsevier, USA. pp. 109-124.

https://doi.org/10.1016/B978-0-12-397003-9.00006-0

Cramon-Taubadel V., Ling E., Cotter D., et al. 2005. Determination of body shape variation in Irish hatchery-reared and wild Atlantic salmon. J. Fish Biol. 66: 1471-1482. https://doi.org/10.1111/j.0022-1112.2005.00698.x

Dumont H. 1998. The Caspian Lake: history, biota, structure, and function. Limnol Oceanogr. 43: 44-52. https://doi.org/10.4319/10.1998.43.1.0044

Espinosa-Lemus V., Arredondo-Figueroa J.L., Barriga-Sosa I 2009. Morphometric and genetic characterization of tilapia (Cichlidae: Tilapiini) stocks for effective fisheries management in two mexican reservoirs. Hidrobiológica 19: 95-107.

Favaloro E., Mazzola A. 2003. Shape change during the growth of sharpsnout seabream reared under different conditions in a fish 
farm of the southern Tyrrhenian Sea. Aquacult. Eng. 29: 57-63. https://doi.org/10.1016/S0144-8609(03)00050-5

Ginzburg A.I., Kostianoy A.G., Sheremet N.A. 2005. Sea surface temperature variability, The Caspian Sea Environment. Springer, pp. 59-81.

Guenette S., Rassart E., Fortin R. 1992. Morphological differentiation of lake sturgeon (Acipenser fulvescens) from the St. Lawrence river and Lac des Deux Montagnes (Quebec, Canada). Canadian J. Fish. Aquat. Sci. 49: 1959-1965. https://doi.org/10.1139/f92-217

Hanson K., Hasler C., Suski C., et al. 2007. Morphological correlates of swimming activity in wild largemouth bass (Micropterus salmoides) in their natural environment. Comp. Biochem. Physiol. Part A: Mol. Integrat. Physiol. 148: 913-920. https://doi.org/10.1016/j.cbpa.2007.09.013

Hilton E.J., Schaefer S. 2002. Observations on rostral canal bones of two species of Acipenser (Actinopterygii, Acipenseriformes). Copeia 2002: 213-219.

https://doi.org/10.1643/0045-8511(2002)002[0213:OORCBO] 2.0.CO;2

Keenlyne K., Henry C., Tews A., et al. 1994. Morphometric comparisons of upper Missouri River sturgeons. Trans. Am. Fish. Soc. 123: 779-785. https://doi.org/10.1577/1548-8659(1994)123<0779:MCOUMR $>2.3 . \mathrm{CO} ; 2$

Khoshkholgh M., Pourkazemi M., Nazari S., et al. 2011. Genetic diversity in the Persian sturgeon, Acipenser percicus, from the south Caspian Sea based on mitochondrial DNA sequences of the control region. Caspian J. Env. Sci. 9: 17-25.

Kishida M., Kanaji Y., Xie S., et al. 2011. Ecomorphological dimorphism of juvenile Trachurus japonicus in Wakasa Bay, Japan. Environ. Biol. Fish. 90: 301-315. https://doi.org/10.1007/s10641-010-9743-5

Langerhans R.B., Reznick D.N. 2010. Ecology and evolution of swimming performance in fishes: predicting evolution with biomechanics. In: Domenici P., Kapoor B.G. (eds), Fish locomotion: an eco-ethological perspective. Science Publishers, Enfield, NH, USA, pp. 200-248. https://doi.org/10.1201/b10190-8

Mazlomi M., Hoseinzadeh Sahafi H., Salavatian M., et al. 2009. Recognation the existent status of restocking programs in the Caspian Sea, Iranian Fisheries Research Organization, Tehran, $284 \mathrm{pp}$.

Michel M.J., Chevin L.M., Knouft J.H. 2014. Evolution of phenotype-environment associations by genetic responses to selection and phenotypic plasticity in a temporally autocorrelated environment. Evolution 68: 1374-1384. https://doi.org/10.1111/evo.12371

Mirzajani A., Ghaninezhad D., Ghane S.S.A. 2005. The relation between fish catches values and macrobenthic biomass in Caspian Sea of Guilan province. Pajouhesh va Sazandegi. 18: 2-9.

Moghim M., Kor D., Tavakolieshkalak M., et al. 2006. Stock status of Persian Sturgeon (Acipenser persicus Borodin, 1897) along the Iranian coast of the Caspian Sea. J. Appl. Ichthyol. 22: 99-107. https://doi.org/10.1111/j.1439-0426.2007.00935.x

Monet G., Uyanik A., Champigneulle A. 2006. Geometric morphometrics reveals sexual and genotypic dimorphisms in the brown trout. Aquat. Living Res. 19: 47-57. https://doi.org/10.1051/alr:2006004

Motta P.J., Norton S.F., Luczkovich J.J. 1995. Perspectives on the ecomorphology of bony fishes. Environ. Biol. Fish. 44: 11-20. https://doi.org/10.1007/BF00005904

Pakkasmaa S., Piironen J. 2001. Morphological differentiation among local trout (Salmo trutta) populations. Biol. J. Linnean Soc. 72: 231-239. https://doi.org/10.1111/j.1095-8312.2001.tb01313.x

Quinn G.P., Keough M.J. 2002. Experimental design and data analysis for biologists. Cambridge University Press. https://doi.org/10.1017/CBO9780511806384
Rohlf F. 2006. tpsDig2, Version 2.1. State University of New York, Stony Brook.

Ruban G. 1989. Clinal variation of morphological characters in the Siberian sturgeon, Acipenser baeri, of the Lena basin. J. Ichthyol. 29: 48-55.

Ruban G., Sokolov L. 1986. Morphological variability of Siberian sturgeon, Acipenser baeri, in the Lena River in relation with its culture in warm waters. J. Ichthyol. 26: 88.

Russo T., Costa C., Cataudella S. 2007. Correspondence between shape and feeding habit changes throughout ontogeny of gilthead sea bream Sparus aurata L., 1758. J. Fish Biol. 71: 629-656. https://doi.org/10.1111/j.1095-8649.2007.01528.x

Russo T., Pulcini D., O'Leary A., et al. 2008. Relationship between body shape and trophic niche segregation in two closely related sympatric fishes. J. Fish Biol. 73: 809-828. https://doi.org/10.1111/j.1095-8649.2008.01964.x

Russo T., Pulcini D., Bruner E., et al. 2009. Shape and size variation: growth and development of the dusky grouper (Epinephelus marginatus Lowe, 1834). J. Morphol. 270: 83-96. https://doi.org/10.1002/jmor.10674

Russo T., Pulcini D., Costantini D., et al. 2012. "Right" or "wrong"? insights into the ecology of sidedness in european flounder, Platichthys flesus. J. Morphol. 273: 337-346. https://doi.org/10.1002/imor.11027

Sheehan T.F., Kocik J.F., Cadrin S.X., et al. 2005. Marine growth and morphometrics for three populations of Atlantic salmon from eastern Maine, USA. Trans. Am. Fish. Soc. 134: 775-788. https://doi.org/10.1577/T04-067.1

Taft N.K. 2011. Functional implications of variation in pectoral fin ray morphology between fishes with different patterns of pectoral fin use. J. Morphol. 272: 1144-1152. https://doi.org/10.1002/jmor.10970

Tancioni L., Russo T., Cataudella S., et al. 2013. Testing species delimitations in four Italian sympatric leuciscine fishes in the Tiber River: a combined morphological and molecular approach. PLoS One 8: e60392. https://doi.org/10.1371/journal.pone.0060392

Tavakoli M., Khoshghalb M.R., Hadadi Moghadam K., et al. 2009. Stock assessment of sturgeon fish in the south Caspian Sea, Iranian Fisheries Research Organization, Tehran. 129.

Toscano B.J., Pulcini D., Hayden B., et al. 2010. An ecomorphological framework for the coexistence of two cyprinid fish and their hybrids in a novel environment. Biol. J. Linnean Soc. 99: 768-783. https://doi.org/10.1111/j.1095-8312.2010.01383.x

Vasil'eva E.D. 2009. Morphological and morphometric characters in sturgeon taxonomy and phylogeny, Biology, Conservation and Sustainable Development of Sturgeons. Springer, pp. 51-61.

Vecsei P., Peterson D. 2005. Sturgeon ecomorphology: a descriptive approach. Sturgeons and Paddlefish of North America. Springer, pp. 103-133.

Walsh M.G., Bain M.B., Squiers T., et al. 2001. Morphological and genetic variation among shortnose sturgeon Acipenser brevirostrum from adjacent and distant rivers. Estuaries 24: 41-48. https://doi.org/10.2307/1352811

Wessel M.L., Smoker W.W., Joyce J.E. 2006. Variation of morphology among juvenile Chinook salmon of hatchery, hybrid, and wild origin. Trans. Am. Fish. Soc. 135: 333-340. https://doi.org/10.1577/T04-078.1

Wintzer A., Motta P. 2005. Diet-induced phenotypic plasticity in the skull morphology of hatchery-reared Florida largemouth bass, Micropterus salmoides floridanus. Ecol. Freshwat. Fish 14: $311-318$. https://doi.org/10.1111/j.1600-0633.2005.00105.x

Zar J. 1996. Biostatistical Analysis, 3rd ed., Prentice Hall, New Jersey.

Zelditch M.L., Swiderski D.L., Sheets H.D. 2012. Geometric morphometrics for biologists: a primer. Academic Press. 